Mohd Ali Samsudin, Vasugi Subramaniam, Moses Irekpita Simeon. (2015). Comparing The Effect of Inquiry-based Multiple Intelligence Approach and Noninquiry based Multiple Intelligence Approach on Achievement in Science. Journal of Education and Learning. Vol. 9 (4) pp. 282-287.

\title{
Comparing the Effect of Inquiry-Based Multiple Intelligence Approach and Non-Inquiry Based Multiple Intelligence Approach on Achievement in Science
}

\author{
Mohd Ali Samsudin* \\ Universiti Sains, Malaysia \\ Vasugi Subramaniam $^{* *}$ \\ Universiti Sains, Malaysia \\ Moses Irekpita Simeon ${ }^{* * *}$ \\ Universiti Sains, Malaysia
}

\begin{abstract}
The paper focused attention on comparing the effect of inquiry based multiple intelligence approach and noninquiry based multiple intelligence approach on achievement of pupils in some selected primary schools. Two primary schools were selected purposively with one intact class from each school. Each intact class of thirty (30) pupils were randomly assigned to the two groups used for the study. A total of sixty (60) pupils were used in the study. The two groups were assigned each to the inquiry based multiple intelligence approach group and the noninquiry based multiple intelligence approach group. The research design was a quasi-experimental design, involving a pretest and post-test in achievement of students. The reliability of the test instrument was established at 0.75 which was considered adequate. A pretest- was administered to the pupils. The pupils were taught science concepts based on the curriculum of the ministry of education for a period of eight (8) weeks using the inquirybased multiple intelligence approach and non- inquiry multiple intelligence approach for group A and B respectively after which the post-test- was administered. Findings using the statistical techniques of mean, median, standard deviation and one way analysis of covariant (ANCOVA) were used to proffer answers to the generated research questions and hypotheses revealed that there was significant difference between the achievement scores of pupils in science for the use of non- inquiry based multiple intelligence approach and noninquiry based multiple intelligence approach on. It was also statistically established that the effect of inquiry based multiple intelligence approach was on achievement is science was better. Conclusion and recommendations such as introducing and enhancing the use of inquiry based multiple intelligence approach in primary schools was made.
\end{abstract}

Keywords: Multiple Intelligence, Inquiry-based, Achievement in Science

\footnotetext{
* Dr. Mohd Ali Samsudin. School of Educational studies Universiti Sains Malaysia (USM), 11800, Penang, Malaysia.

E-mail: alisamsudin@usm.my
** Vasugi Subramaniam, School of Educational studies Universiti Sains Malaysia (USM), 11800 Penang, Malaysia.

**** Moses Irekpita Simeon, School of Educational studies Universiti Sains Malaysia (USM), 11800, Penang, Malaysia. Email:

E-mail: simeon20012003@yahoo.com
} 


\section{Introduction}

Science is the bedrock for technological advancement and nation building so that its development is critical to the development and well being of the citizenry. Science according to Garuba, Agweda and Abunere (2012) embraces every intentions of man to explore and interpret the world around him. According to them, science is dynamic and is concerned with the search for explanation of causes and effects in nature. Its purpose is to transform the human environment to live an improved and qualitative life in all its ramifications.

Unfortunately, as rosy as the impact of science on humans and his environment could be, students' achievement in science examinations is discouraging. Harry (2011) decried that there is a low, poor and discouraging performance and enrollment in science in recent years so that there is a need to evolve new strategies or approach to teaching, science. This therefore becomes the basis for which this study on comparing the effect of two instructional methods namely the inquiry based multiple intelligence approach and non-inquiry multiple intelligence approach in achievement in science was carried out.

Multiple intelligence theory stresses on providing equal opportunities to accessing educational concept and delivery. Multiple intelligence emphasizes that intelligence is not inherited but can be development by polishing the dominant intelligence so that every everybody is somebody within a classroom set-up. Multiple intelligence according to Moran, Konhaber and Gadner (2006) is an approach with evaluate learners ability to develop there own skills and not merely on test scores. Gangi (2011) observed that each person has several distinct intelligences. .Intelligence according to Owolabi and Okebukola (2009) presupposes that an array of different kinds of intelligence exists in human beings. Gardner (1983) observed that all human beings posses nine intelligences but in varying amount namely as linguistic intelligence, logical mathematical intelligence, visual spatial intelligence, musical intelligence, bodily kinesthetic intelligence, interpersonal, intrapersonal as well as spiritual intelligence. Meanwhile, inquiry in science teaching plays at least two different roles. Inquiry Based Learning involves a systematic process of natural or material world trigger to initiate questions, find new things and testing it to obtain new array of knowledge (Ekeyi, 2013). It is geared by an individual's own curiosity, wonder and passion to solve any emerging problem and communicate the received knowledge. Inquiry is the ground where learner constructs a new mental framework of the natural or material world. Inquiry learning approach is making meaning of experience. The rationale for infusing inquiry- based approach in multiple intelligence activities is to ensure that the students learn actively in inquiry manners but using their own learning styles based on their preferred type of intelligence. $5 \mathrm{E}$ learning cycle model was used to operationalize the inquiry based approach in multiple intelligence activities. 5E was consisted of five stages of learning which were Explore, Engage, Explain, Elaborate and Evaluate. Inquiry-based learning begins by posing questions, problems or scenarios rather than simply presenting established facts or portraying a smooth path to knowledge as done in a traditional class setting. The process is often assisted by a teacher. Inquirers will identify and research issues and questions to develop their knowledge or solutions. The inquiry-based instruction is essentially very closely related to the thinking and its development (Dostal, 2015). Non-inquiry based multiple intelligence approach involve multiple intelligence activities which are conducted based on linear steps without using $5 \mathrm{E}$ learning cycle while the inquiry approach focuses on initiating questions on what they have learnt. Its conducts activities for learners based on what has been assigned.

\section{Research Methodology}

The study employed a quasi experimental research design which compares two groups namely the Inquiry- based multiple Intelligence group and the non-inquiry- based multiple intelligence group. Two intact classes of primary five pupils from two different schools were used in the study. Pupils were assigned into the two (2) also groups with thirty (30) in each group giving a total of sixty (60) subjects in the study. Pupils in group A (inquiry-based multiple intelligence) were exposed to energy concept in science while pupils in the group B (non-inquiry based multiple intelligence approach) the same for eight (8) weeks. Before the interventional both groups were subjected to pretest on Science Achievement Test (SAT) and after the intervention a post-test was also administered to the two groups although with the same questions re-shuffled for the post-test.

In the first week treatment activities was on verbal linguistic intelligence was carried out, second week on logical mathematical intelligence, third on visual spatial intelligence; fourth week on interpersonal intelligence, fifth on musical intelligence. Sixth week was on naturalistic intelligence, seventh on kinesthetic intelligence while in the eight week pupils were introduced to interpersonal intelligence. For the inquiry- based multiple intelligence approach careful preparation was observes to ensure the treatment focuses not only on the fun element but also permits active learning to occur. In 
order to incorporate inquiry into multiple intelligence $5 \mathrm{E}$ learning cycle was utilized to ensure the instructional goal was achieved. The 5E learning model consists of five (5) stages which are elaboration, engagement, exploration, explanatory and evaluation. The research design is given in table 1 below:

Table 1. Research Design

\begin{tabular}{lllll}
\hline Group & & \multicolumn{2}{c}{ Treatment } \\
\hline \multicolumn{2}{c}{ Experimental Group A $(\mathrm{N}=30)$} & $0_{1}$ & $\mathrm{X} 1$ & $0_{2}$ \\
& Experimental Group B $(\mathrm{N}=30)$ & $0_{1}$ & $\mathrm{X} 2$ & $0_{2}$ \\
\hline 01 & - Pretest & & \\
02 & - Post-test & & \\
$\mathrm{X} 1$ & - Inquiry based multiple intelligence approach \\
$\mathrm{X} 2$ & - Non-Inquiry based multiple intelligence approach
\end{tabular}

From table 1 above, the pupils were assigned into 2 groups (each group with 30 subjects). Pupils in the experimental group1 were exposed to the lesson using inquiry-based multiple intelligence approach meanwhile pupils in experimental group 2 were taught the same topic using non inquirybased multiple intelligence approach for 8 weeks. The summary of the entire procedure is highlighted in table 2 below:

Table 2. Summary of Main Procedure of the Study

\begin{tabular}{ll}
\hline Week & Research Activity \\
\hline 1 & Science Achievement test (SAT) Pre-test \\
$2-9$ & $\begin{array}{l}\text { Intervention (inquiry based multiple intelligence approach for experimental group A and no- inquiry based multiple } \\
\text { intelligence approach) }\end{array}$ \\
10 & Science Achievement test (SAT) Post-test \\
\hline
\end{tabular}

From table 2 above before the intervention period, the pupils from experimental group1 and experimental group 2 were given pre-test. After the pre-test, the pupils in experimental group 1 and experimental group 2experienced intervention period for eight weeks. After the intervention period, the pupils from both experimental groups were given post-test. The Science Achievement Test (SAT) was administered to measure the achievement of pupils in science using the intervention. The test consists of 15 Multiple Choice Questions (MCQ) and two (2) structured questions aligning with inquiry and noninquiry based multiple intelligence approach. The test items were based on bloom's taxonomy with item specifications for the fifteen (15) items comprising of low, medium and difficult questions. The test items were in conjunction with the curriculum specification of the ministry of education.

\section{Findings and Discussion}

Findings obtained as shown in tables 3 below shows that the pupils in inquiry-based multiple intelligence group (group A) had a higher achievement test-score in science (SAT) compared to those in the non-inquiry-based multiple intelligence approach, thus answering the research question which asked if there was any significant differences in achievement in achievement of pupils taught science using inquiry-based multiple intelligence approach and those taught with non-inquiry based multiple approach? It was therefore proven that inquiry based multiple intelligence is more effective than the non-inquiry multiple intelligence in enhancing cognitive development of pupils in science. The mean, median and standard deviation for the pre-test and post -test achievement in science is giving as follows:

Table 3. The mean, median, standard deviation, minimum and maximum scores of pre-test and posttest for achievement test in science.

\begin{tabular}{lll}
\hline & Pre-Test score & Post-test score \\
\hline $\mathrm{N}$ & 60 & 60 \\
Mean & 11.83 & 16.58 \\
Median & 12.50 & 18.00 \\
Standard deviation & 3.29 & 5.04 \\
Minimum & 2.00 & 3.00 \\
Maximum & 16.00 & 24.00 \\
Skewers & -1.36 & -0.84 \\
Kurtosis & 1.78 & 0.12 \\
\hline
\end{tabular}


To compare the effects of Inquiry -based multiple intelligence approach and non-inquiry multiple intelligence approach a One-Way ANCOVA analysis was carried out as follows:

Table 4. The results of ANCOVA for the post-test mean score for Achievement in science for inquirybased multiple intelligence approach group and non-inquiry based multiple intelligence approach group and the pretest mean score as the covariates.

Dependent variable: post test mean score for achievement in science

\begin{tabular}{lllllll}
\hline Source & Type II Sum of square & df & Mean square & F & Sig & Partial eta square \\
\hline Corrected model & $1358.754 a$ & 2 & 679377 & 296.941 & .000 & 0.907 \\
Intercept & 144.275 & 1 & 144.275 & 58.812 & .000 & .508 \\
Pretest mean score & 390.737 & 1 & 390.737 & 159.280 & .000 & .736 \\
Group & 398.710 & 1 & 398.710 & 162.530 & .000 & .740 \\
Error & 139.829 & 57 & 2.453 & & .000 & \\
Total & 1799.000 & 60 & & & & \\
Corrected total & 1498.583 & 59 & & & & \\
\hline a. R squared $=.907$ ( Adjusted squared = .903) & \multicolumn{5}{c}{} \\
b. Generated using alpha $=.05$
\end{tabular}

Result obtained from table 4 above on the analysis of one way ANCOVA shows that F value $(1,57)=162.53, p<0.05$. This result implies that there was significant different between the achievement of pupils taught science by inquiry based multiple intelligence approach and those taught science by non-inquiry-based multiple intelligence approach. The effect size between the inquiry based multiple intelligence approach and non-inquiry based multiple intelligence approach with the post-test mean score is indicated by partial eta squared value which is 0.74 . The estimated marginal means generated by ANCOVA post-test mean score for achievement in science for inquiry based multiple intelligence and non-inquiry multiple intelligence after the difference in pre-test mean score in Achievement in science was controlled is shown in table 5 below:

Table 5. The estimated marginal means for post-test mean scores of achievement in science and standard error for inquiry based multiple intelligence approach and non inquiry based multiple intelligence approach.

\begin{tabular}{lcccc}
\multicolumn{3}{c}{ Dependent variable: post test mean score achievement in science } \\
\hline Group & Mean & Standard Error & \multicolumn{2}{c}{$\begin{array}{c}\text { 95\% confidence interval } \\
\text { Lower bound }\end{array}$} \\
& & & Upper bound \\
\hline Inquiry based multiple intelligence & $19.422^{\mathrm{a}}$ & .301 & 18.820 & 20.025 \\
Non-inquiry based multiple intelligence & $13.744^{\mathrm{a}}$ & .307 & 13.142 & 14.347 \\
\hline
\end{tabular}

a. Evaluated based on covariate in the model.

Result obtained from table 5 above shows the estimated marginal means generated by ANCOVA post-test mean score for achievement in science for inquiry based multiple intelligence is 19.42 which is comparatively higher than the post test mean score of 13.74 for non-inquiry multiple intelligence after the difference in pre-test mean score in Achievement in science was controlled. This therefore implies that the inquiry based multiple intelligence approach is effective in boosting pupils' achievements in science. This is in line with the findings of Pyatt and Sims (2007) who reported that inquiry- based multiple intelligence approach triggers students' ability to effectively participate in classroom discussion thus prompting their social and cognitive development. This was also supported by Thompson and MacDougall (2002) who pointed out that inquiry based multiple intelligence approach encourages students to solve problems encountered rather the conventional rote learning memorization of facts. The finding is also consistent with that of Opara (2011) who investigated the effect of inquiry method on students academic achievement in biology and reported that inquiry teaching method has a significant effect on students achievement and that teaching method has greater positive effect on students achievement in science. Also study was found to be in line with the study of Kaya (2008) who in his study reported that multiple intelligence enhances students understanding in science

Inquiry according to Jiang and McComas (2015) as a practice engaged in by scientists should be taught as part of science curriculum. Secondly, and perhaps more importantly, inquiry according to them should be used as a pedagogical tool through which students can learn science content as well as 
practice the process of inquiry through experience. Inquiry has been described by the National Science Education Standards (National Research Council, 1996) as a set of science practices and activities that involves making observations; posing questions; analysing sources of information such as books in a bid to check out what is already known ;It involves planning, investigations; reviewing what is already known in the light of experimental evidence; using necessary tools to gather, analyze, and interpret data; proposing answers, explanations, and predictions; and communicating the results. Before now, inquiry teaching was often connected to the concept of 'discovery teaching (Jiang, et al 2015). Inquiry-based learning is primarily a pedagogical method, developed during the discovery learning movement of the 1960s as a response to traditional forms of instruction - which is based memorizing information from instructional materials (Bruner, 1961). The philosophy of inquiry- based learning finds its antecedents in constructivist learning theories which emphasize student centered learning.

\section{Conclusion}

Results obtained from analysis of data in this study shows that the inquiry- based multiple intelligence approach was better in terms of enhancing pupils' achievement in science compared to the non-inquiry based multiple intelligence approach. The result of the analysis also shows that the inquiry based multiple intelligence are more effective than non- inquiry based multiple intelligence in enhancing pupils' cognitive development in science. Owing to the findings in this study, it is therefore recommended that:

(i) The use of multiple intelligence teaching approach should be initiated and encouraged at primary schools levels for teaching science.

(ii) School authorities should initiate the introduction of informal science learning using inquiry based multiple intelligence approach at primary schools.

\section{Acknowledgment}

This research was funded by Universiti Sains Malaysia (USM) Research Grant (1001/PGURU/816163)

\section{References}

Bruner, J. (1961). The act of Discovery. Harvard Educational Review. 31(1)21-32

Dostál, J. (2015). Inquiry-based instruction: Concept, essence, importance and contribution. Olomouc: Palacký University, doi 10.5507/pdf.15.24445076

Ekeyi, D.N (2013). Effect of Demonstration method of Teaching on Students Achievement in Agricultural science. World Journal of Education3(6),78-94

Gardner H. (1983). Frames of mind. The Theory of Multiple Intelligence. New York Basic Books.

Garuba, M.A, Agweda, F.E., Abunere, D.I. (2012). The contribution of science and Technology to National Development: The Nigeria experience. Journal of Education and Practice 3(1).

Gangi S. (2011). Differentiating instruction using multiple intelligence in the elementary schools classroom: A Literature Review (Doctoral Dissertations, University of Wisconsin-.stout. United States).

Harry, I.H. (2011) Attitude of students towards science and science education in Nigeria ( A case study in selected secondary school in Obio/Akpan local government area of Rivers State. Continental Journal_of Education Research_4(2) 33-51

Jiang, F \& McComas (2015). Effect of Inquiry Teaching on Student Science Score Achievement and Attitude: Evidence of Propensity From Score Analysis of PISA Data . International Journal of Science Education, 37(3), 554-576, DOI: 10.1080/09500693.2014.1000426. 
Kaya O.N. (2008). How is Science Lesson Developed and Implemented Based on Multiple intelligences Theory? Haccettepe University Journal of Education 34,155-167

Moran S., Kornhaba M. \& Gardner H. (2006). Orchestrating Multiple Intelligence. Educational Leadership 64(1)22-27.

National Research Council. (1996). National science education standards. Washington, D.C.: The National Academies Press

Opara J. (2011). Inquiry Method and students academic achievement in biology: Lessons and Policy. .American -Eurasian Journal of Scientific Research, 6(1)28-31

Owolabi T \& Okebukola F. (2009) Improving the reading ability of science students through study groups and multiple intelligences. US-China_Education_Review 6(2) 38-44.

Pyatt, K.A. \& Sins, R. (2007). Learner performance and Attitudes in traditional versus situation laboratory experiences. Journal of science Education and Technology 21(1) 133-147 doi 10.1007/, 1081-011-9291-6.

Thompson, B.R. \& MacDougall, G.D. (2002). Intelligence Teaching using the theory of multiple intelligence in the inquiry classroom. Science Teacher Washington 69(1), 44-48. 